\title{
YY super males have better spermatic quality than XY males in red tilapia Oreochromis niloticus
}

\author{
David Salirrosas; Julio Leon; Monica Arqueros-Avalos; Linda Sanchez- \\ Tuesta; Fernanda Rabanal; Zulita Prieto*
}

Facultad de Ciencias Biológicas, Universidad Nacional de Trujillo. Av. Juan Pablo II s/n. Ciudad Universitaria, Trujillo, Peru.

Received April 5, 2017. Accepted September 24, 2017.

\begin{abstract}
The influence of sex-related chromosomal arrangement in an YY and XY population of Oreochromis niloticus males was investigated in this study. A better spermatic mobility, motility, viability, confluence and less abnormality were found in double Y-chromosome males (YY-males), compared to XY-males; however, this better spermatic quality did not correlate with the body weight of individuals which was significantly better in $\mathrm{XY}$-males. This study establishes the influence of YY-related sequences over spermatic quality and indicates the usefulness of the YY technology as a strategy to obtain better fish breeders and genetically male individuals for a tilapia farming program.
\end{abstract}

Keywords: Oreochromis niloticus; tilapia; spermatic quality; YY males.

\section{Introduction}

Oreochromis niloticus is a bisexual fish with the sexual chromosome arrangement of XX for females and XY for males. Phenotypic males often show better advantages such as faster weight and length gain (Githukia et al., 2015) and it is preferred to ensure high productivity and reproductive capability in tilapia farming. Weight records of monosex and mixed populations demonstrate the male monosex superiority (Omasaki et al., 2016). One of the most used strategies to ensure monosex individuals is the use of hormonal treatments (Gale et al., 1999; Beaven and Muposhi, 2012; Megbowon and Mojekwe 2014). Other methods that are safer for the environment include hybrid crosses of Oreochromis niloticus females with Oreochromis aureus males (Lozano et al., 2014) or between YY super male with XX female individuals to ensure genetically determined males (Alcántar-Vásquez et al.,

* Corresponding author

E-mail: zprieto@unitru.edu.pe (Z. Prieto).
2014; Schill et al., 2016). Monosex males obtained by the latter case exhibit many advantages over the hormonal treatment, including faster development and homogeneous growth, reducing farming costs and possible immunological detriments in the male population caused by hormonal treatments (Beardmore et al, 2001). Although the YY super male technology is spreading widely over the world, only few reports have analyzed gamete quality in tilapia males which, despite the fact that they are phenotypically males, have the YY or XY arrangement that could potentially influence in their reproductive capability.

Besides the quality of the eggs, spermatic quality is a key factor for the reproductive success of tilapia. Few studies have reported the same sperm quality of $\mathrm{XX}$ masculinized-males, XY males and YY males (Rurangwa et al., 2004; Gennotte et $a l .$, 2012). However, even if the genetic

(C) 2017 All rights reserved. DOI: 10.17268/sci.agropecu.2017.04.06 
background of the stock is similar, we asked whether the sexual chromosome arrangement and the introduction to a new environment could potentially influence the spermatic quality of male monosex tilapia.

There exist several lineages of $O$. niloticus, including $O$. niloticus grey, $O$. niloticus red and $O$. niloticus silver, which are broadly distributed in several countries and show different phenotypes. In Peru, the predominant lineage is $O$. niloticus grey, that have been farmed and bred empirically without major scientific strategies. The introduction of exogenous lineages with favorable phenotypes, along with the use of monosex technology, may represent a good strategy to increase productivity. However, it is necessary to assess the reproductive characteristics of newly introduced lineages, since they may respond differently to the new environment and exhibit variations in its phenotype.

In order to delineate strengthens of the YY technology for a breeding program and also to better understand the influence of the sex genotypes on spermatic quality, the spermatic quality of an introduced population of male red tilapia $O$. niloticus with YY and XY genetic rearrangement was compared.

\section{Material and methods}

\section{Fishes}

Live specimens of Oreochromis niloticus red were obtained from Tilaqua (The Netherlands). Twenty 21-month-old individuals of each type, YY and XY male, were selected for the study. All individuals were kept at $24 \pm 2{ }^{\circ} \mathrm{C}$ of temperature, $5-8$ $\mathrm{mg} / \mathrm{l}$ of oxygen, 7 of $\mathrm{pH}, 45 \mathrm{~cm}$ of water transparency and $14 \mathrm{~h}$ light / $10 \mathrm{~h}$ darkness photoperiodic regime. Feeding was carried out three times a day with a commercial available diet composed by $40 \%$ proteins, $8 \%$ lipids, $4 \%$ fiber, $13 \%$ humidity and $10 \%$ ashes.

\section{Genotyping}

The presence of Y-related and X-related sequences was confirmed as described by
Sun et al. (2014). Briefly, DNA was extracted from caudal fins with standard procedures and subjected to PCR with the primers

SCAR-5F TAAATTAATGACATTTCAGTTATG and

SCAR-5R-Y TTACAGCAGCACCCAGAGTCAT

for the Y-related sequence; and

SCAR-5-X CTGGTTTGCAATAGTTAGGGTGCT and

SCAR 5R CAGAAATGTAGACGCCCAGGTATC for the X-related sequence.

\section{Sperm quality parameters}

Sperm was obtained through extrusion or massage on the abdominal region as previously described by Piñeros-Piñeros and Cala-Cala (1991). Sperm sampling and handling from all YY and XY individuals was performed in the same scheduling time. The quality parameters assessed were: volume, mobility, motility, viability, morphology and sperm density as described by Bastardo et al. (2004) and Sánchez-Rodríguez and Billard (1977). The sperm volume was measured using a graduated-1 $\mathrm{ml}$ syringe. The mobility was determined by assessing 100 cells in $8-10$ fields and classified as rapid and linear progressive movement (Bastardo et al., 2004), slow progressive movement, in situ movement, and immobile sperm. The motility was obtained using an optic microscope at $100 \mathrm{X}$ magnification after activation with farming water at $24 \pm 2{ }^{\circ} \mathrm{C}$ with oxygen $4.77 \mathrm{mg} / \mathrm{l}$. The degree of motility was estimated using arbitrary units as described by Sánchez-Rodríguez and Billard (1977). Viability was performed by dead cells exclusion using propidium iodide (PI) and evaluated using a fluorescent microscope with specific filters and differential interference contrast (DIC). 100 cells were counted from 5 fields from 3 different individuals, and the DIC pictures were also used to assess sperm morphology.

\section{Statistical analysis}

Mean values comparisons were performed using $\mathrm{t}$ student test with a significance level of $\alpha=0.05$. 


\section{Results and discussion}

Besides a morphological assessment to determine the phenotypic gender, $\mathrm{XY}$ and YY genotypes were identified with the markers SCAR-5F-X/5R and SCAR5F/5R-Y by conventional PCR (Figure 1A) as previously described (Sun et al., 2014). Then, a morphological analysis was performed to study the gender genotype influences on important economical parameters such as weight and length. There was found that XY males had more than 1.5-fold significant higher weight average compared to YY males (Figure 1B). However, body length of $\mathrm{XY}$ and $\mathrm{YY}$ males were similar (Figure 1C and 1D).

Later, the work was focused on assessing the sperm quality parameters. First of all, the spermatic volume was measured (Figure 2A) and sperm viability from XY and YY males was evaluated using propidium iodide (PI) as indicator of dead cells, finding no significant differences (Figure 2B). However, the sperm confluence of the YY males was about 2.4-fold higher than the confluence from $\mathrm{XY}$ males sperm collected (Figure 2C).

Spermatic cells were classified and quantified according to its mobility as previously described (Bastardo et al.,
2004) (Figure 3A): rapid linear movement (RL), slow movement (S), in situ movement (IS) and immobile (I). Spermatic cells derived from either YY or XY males were categorized as I in over 90 per cent. Although were found no significant differences among the percentage of cells with S, IS and I, a higher percentage with RL was found in YY sperm cells, compared to $\mathrm{XY}$ phenotypes. In this research, XY males had better phenotype regarding to its weight gain; however, XY males had lower reproductive capability as demonstrated with lower sperm viability, volume, confluence and mobility.

The sperm confluence reported in this study was the highest reported for YY male tilapia (Gennotte et al., 2012; Bombardelli et al., 2010; Mataveli et al., 2007). However, this sperm confluence from YY males was still lower when compared to that from other species (Gennotte et al., 2012). Previous reports established a low sperm confluence in Oreochromis niloticus (Gennotte, et al., 2012), compared to Oncorhynchus mykiis (Piñeros-Piñeros and Cala-Cala et al., 1991), Eremophilus mutisii (Montejo et al., 2002), and Brycon amazonicus (CruzCasallas et al., 2006).

A

B
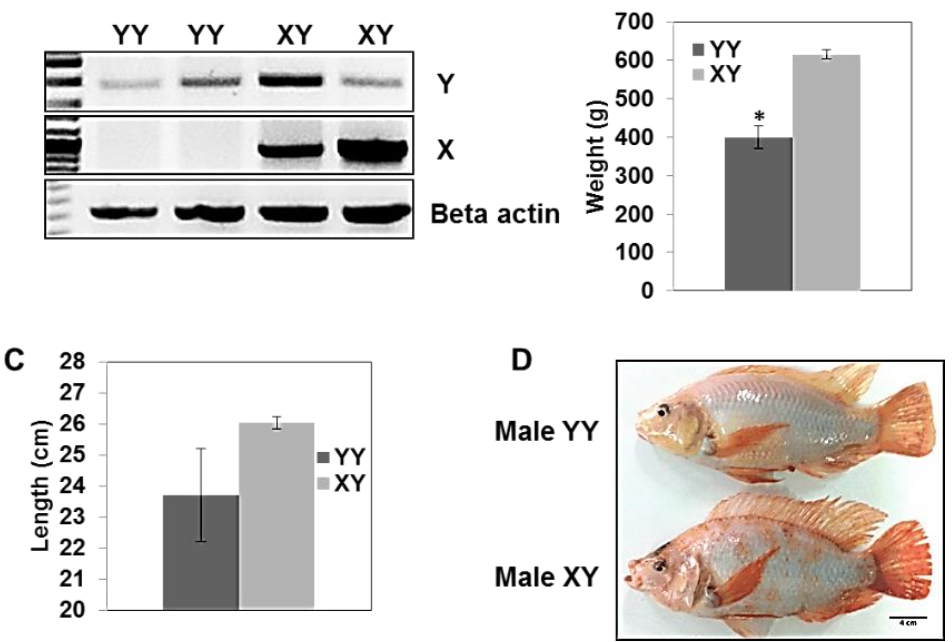

Figure 1. Characterization of $\mathrm{YY}$ and $\mathrm{XY}$ males Oreochromis niloticus red tilapia. A. PCR markers SCAR-5F/5R-Y and SCAR-5F-X/5R, $\beta$-actin internal control. B. Weight mean \pm SD $(n=$ $20), * p<0.05 \mathrm{t}$ test. C. Length average $\pm \mathrm{SD}(\mathrm{n}=20) \mathrm{D}$. YY and XY males, age 21 months. Scale bar $=4 \mathrm{~cm}$. 
A

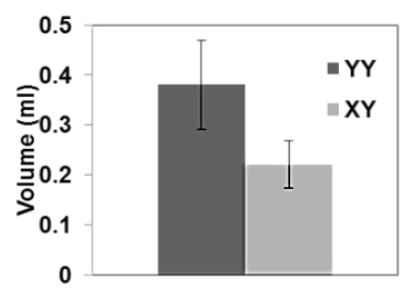

C

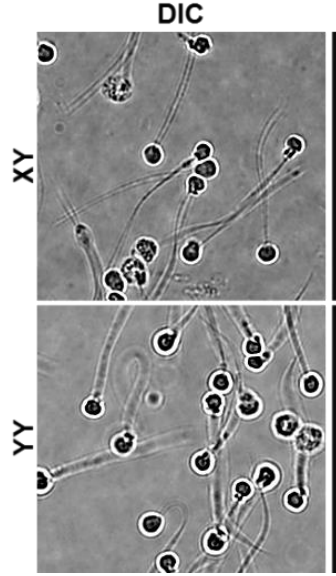

B

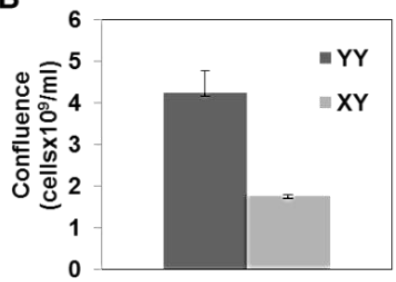

PI

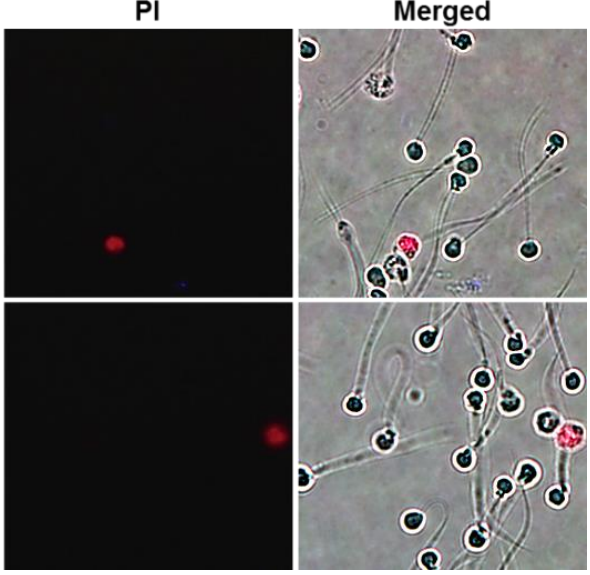

Figure 2. Spermatic quality of $\mathrm{YY}$ and $\mathrm{XY}$ males of Oreochromis niloticus red tilapia. A. Spermatic volume, mean $\pm \mathrm{SD}(\mathrm{n}=20), p<0.05$ t test. B. Spermatic concentration, mean $\pm \mathrm{SD}(\mathrm{n}$ $=20), p>0.05$. C. Sperm viability evaluated with propidium iodide (PI), representative image.

Spermatic cells were then exposed to distilled or farming water to assess its motility. It has been previously shown that spermatic cells increased its motility after exposure to hypotonic water, in a process called "activation" (Billard et al., 1995; Valdebenito et al., 2009). The average time by which the spermatic cells remain activated with either farming or distilled water was significantly higher in those derived from YY genotypes (Figure 3B). The activation time with farming water was in average 32.6 minutes for $\mathrm{XY}$ and 54.7 minutes for $\mathrm{YY}$; and with distilled water 21.9 minutes and 36.3 minutes for $\mathrm{XY}$ and YY males, respectively (Figure 3B).

Sperm mobility without activation is an important parameter that indicates fecundation capability (Bastardo et al., 2004). High levels of sperm cells classified as immobile (90\%) for both, XY and YY males, is an expected feature previously registered (Gennotte et al., 2012).
Nevertheless, the high percentage of sperm cells from YY males with RL, compared to those $\mathrm{XY}$ males, strongly indicates the better reproductive capability of YY males. This is consistent with the results published by Herrera et al. (2001) where YY males showed greater spermatogenic and primordial germ cells, faster sexual maturity and thicker gonadal tissue than $\mathrm{XY}$ male fishes. Contrary to what was stated by Gennotte et al. (2012).

In respect of regulatory mechanism for the testicle development, there would be many miRNA involved which are differentially expressed in $\mathrm{YY}$ an $\mathrm{XY}$ males, causing differences in testicular gonads histology, structure and function among YY an XY male fishes (Jing et al., 2014; Wu et al., 2015).

Moreover, in the activation assay, the motility of YY sperm cells lasted in average $54.7 \pm 30.42 \mathrm{~min}$, significantly longer that the of XY-males. These values were higher than the ones prior reported in 
the study published by Gennotte et al. (2012), where the motility of sperm cells lasted $24 ' 52$ " $\pm 10 ' 40 "$.

To evaluate the morphology of spermatic cells, DIC pictures were used. Cells derived from XY males had a lower percentage of normal cells compared to those derived from YY males, with $78.24 \%$ and $99.71 \%$ respectively (Figure 4A and Figure 4B). Head and tail abnormalities were quantified.
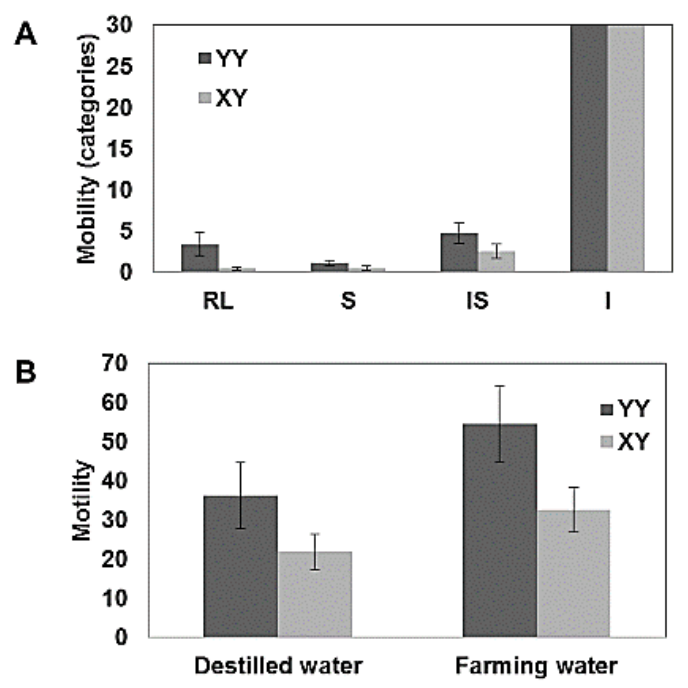

Figure 3. Spermatic mobility and motility of YY and XY males of Oreochromis niloticus red tilapia. A. Mobility (RL: progressive linear rapid movement, $\mathrm{S}$ : progressive slow movement, IS: in situ movement and I: immobile). B. Motility using distilled water (left) and farming water (right). Mean \pm SD (n $=20), p>0.05$.

Morphological abnormalities are usually reported in sperm cells and influence its fecundation capability (Bastardo et al., 2004). Male fishes considered as breeders should ideally have less than $30 \%$ of sperm abnormalities. In this respect, both YY and $\mathrm{XY}$ males outreached this parameter, however, the $99.71 \%$ of normal sperm cells from YY males compared to $78.24 \%$ from $X Y$ males indicates a better capability of fecundation and also ideal individuals for a breeding program.

For the sperm quality assessment, particularly as regards amount of sperm, it is important to keep in mind the reproductive cycle since the spermatogenesis would be synchronized with the female egg maturity, in case of male and female joint breeding. To achieve this synchronization, it would be required a communication through sounds (Longrie et al., 2013) or a chemical communication using pheromones (Li and Buchinger 2014).

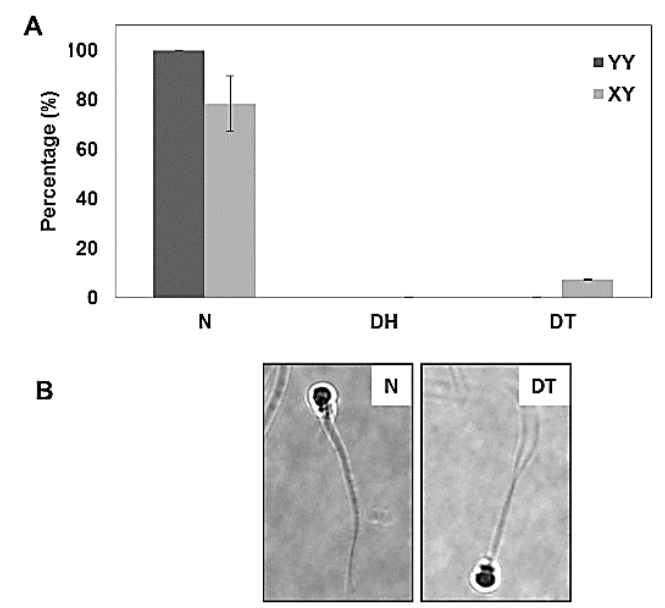

Figure 4. Sperm morphology of $\mathrm{YY}$ and $\mathrm{XY}$ males of Oreochromis niloticus red tilapia. A. Average percentage normal upset sperms, N: normal, DH: defect at the top, DT: defect in tail, mean $\pm \mathrm{SD}(\mathrm{n}=20), p<0.05$. B: Representative image of defect in tail.

It is known that environmental factors influence the spermatic quality of fishes, such as temperature, light exposure, $\mathrm{pH}$ and osmotic changes (Rurangwa et al, 2004, Biswas et al., 2005; Bobe and Labbé, 2010; Legendre et al., 2016), especially when they are farmed in captivity (Zohar and Mylonas, 2001). The meiotic phase of spermatogenesis in $O$. niloticus at $30{ }^{\circ} \mathrm{C}$ is accelerated, whereas at $20{ }^{\circ} \mathrm{C}$ the spermatocytes are stopped in late pachytene, consequently varying the production of sperm (Vilela et al., 2003). Other aspect that also affect spermatic quality are the amount of protein (Moraes et al., 2015; Mewes et al., 2015), hormonal treatments (Mylonas et al., 2017) and, probably, fatty acids in the diet as reported in Anguilla anguilla where it is shown the matching between the fatty acids levels and changes on sperm production and 
spermatic speed (Baeza et al., 2015). Variations in sperm quality depend not only on external changes, but also on the lineage genomic status and epigenetic effects in the regions of DNA involved in primordial cells production and therefore the sperm amount and quality (Robles et al., 2017).

Another aspect that is not greatly studied in fishes is the expression of the microRNA types (miRNA) in male germ cells, that was reported abundantly available in testes of rainbow trout (Farlora et al., 2015), suggesting that the miRNA could be correlated to the spermatogenesis and function of the sperm (Kun-Tong et al., 2015). The significant association between DNA integrity and sperm quality and fertility was reported in other species (Sheikh et al., 2008; Dietrich et al., 2010). The DNA integrity can be affected by environmental or endogenous mutagen during spermatogenesis or spermiogenesis. In this latter process, there is a change in the DNA configuration by an exchange of histones for protamines (Chiva et al., 2011; Gou et al., 2017); therefore, the DNA sequences could be a target for genotoxic agents.

The possible interaction between the sexdetermine DNA sequences and different environmental factors influencing spermatic quality is beyond the scope of this study. Spermatic quality changes over seasonal changes with the subsequent variations in temperature and light exposure.

\section{Conclusions}

Although the XY males had a better performance in terms of weight gain, YY males have better reproductive capabilities based on sperm amount and quality. The YY technology is a valuable and useful strategy to obtain YY breeders with high reproductive capabilities and to ensure a homogeneous population of male monosex $\mathrm{XY}$ with great advantages in weight and length gain. Moreover, it remains to be investigated whether the additional copy of the Y-related sequence and/or the absence of the X-related sequence are key factors that influence the better spermatic quality observed in this study.

\section{Acknowledgments}

This work was financed by the Universidad Nacional de Trujillo with resources of Canon project Genetic Improvement of Tilapia.

\section{References}

Alcántar-Vázquez, J.P.; Moreno-de la Torre, R.; CalzadaRuiz, D.; Antonio-Estrada, C. 2014. Production of YY-male of Nile tilapia Oreochromis niloticus (Linnaeus, 1758) from atypical fish. Latin American Journal of Aquatic Research 42(3): 644-648.

Baeza, A.R.; Mazzeo, I.; Vílchez O.M.M.; Gallego A.V.; Peñaranda, D.S.L.; Pérez I.; Asturiano N.J.F. 2015. Relationship between sperm quality parameters and fatty acid composition of the muscle, liver and testis of European eel. Comparative Biochemistry and Physiology - Part A: Molecular and Integrative Physiology 181: 79-86

Bastardo, H.; Guedez, C.; León, M. 2004. Características del semen de trucha arcoiris de diferentes edades, bajo condiciones de cultivo en Mérida, Venezuela. Zootecnia Tropical 22(3): 277-288.

Beardmore, J.; Mair, G.C.; Lewis, R.I. 2001. Monosex male production in finfish as exemplified by tilapia: applications, problems, and prospects. Aquaculture 197: 283-301.

Beaven, U.; Mupochi, V. 2012. Aspects of a Monosex Population of Oreochromis Niloticus Fingerlings Produced Using 17- $\alpha$ Methyl Testosterone Hormone. Journal of Aquaculture Research and Development 3(3): 1-5.

Billard, R.; Cossonb, J.; Percheca, G.; Linhart, O. 1995. Biology of sperm and artificial reproduction in carp. Aquaculture 129: 95-112.

Biswas, A.K.; Morita, T.; Yoshizaki, G.; Maita, M.; Takeuchi T. 2005. Control of reproduction in Nile tilapia Oreochromis niloticus (L.) by photoperiod manipulation. Aquaculture 243(1-4): 229-239.

Bobe, J.; Labbé, C. 2010. Egg and sperm quality in fish. General and Comparative Endocrinology 165: 535548 .

Chiva, M.; Saperas, N.; Ribes, E. 2011. Complex chromatin condensation patterns and nuclear protein transitions during spermiogenesis: examples from mollusks. Tissue and Cell 43(6): 367-76.

Cruz-Casallas, P.E.; Velasco-Santamaría, Y.M.; MedinaRobles, V.M. 2006. Determinación del espermatocrito y efecto del volumen de la dosis seminante sobre la fertilidad en yamú (Brycon amazonicus). Revista Colombiana de Ciencias Pecuarias 19: 140-145.

Dietrich, G.J.; Dietrich, M.; Kowalski, R. K.; Dobosz, S.; Karol, H.; Demianowicz, W.; Glogowski, J. 2010. Exposure of rainbow trout milt to mercury and cadmium alters sperm motility parameters and reproductive success. Acuat Toxicol. 97 (4): 277-84.

Farlora, R.; Valenzuela-Miranda, D.; Alarcón-Matus P.; Gallardo-Escárate C. 2015. Identification of micro RNAs associated with sexual maturity in rainbow trout brain and testis through small RNA deep sequencing. Molecular Reproduction and Development 82(9): 651662 . 
Gale, W.L.; Fitzpatrick, M.S.; Lucero, M.; ContrerasSanchez, W.M.; Schreck, C.B. 1999. Masculinization of Nile tilapia Oreochromis niloticus/ by immersion in androgens. Aquaculture 178: 349-357.

Gennotte,V.; François, E.; Rougeot, C.; Ponthier, J.; Deleuze, S.; Mélarda, C. 2012. Sperm quality analysis in $\mathrm{XX}, \mathrm{XY}$ and $\mathrm{YY}$ males of the Nile tilapia (Oreochromis niloticus). Theriogenology 78: 210-217.

Githukia, C.M.; Ogello, E.O.; Kembenya, E.M.; Achieng, A.O.; Obiero, K.O.; Munguti, J.M. 2015. Comparative growth performance of male mono- sex and mixed sex Nile tilapia (Oreochromis niloticus L.) reared in earthen ponds. Croatian Journal of Fisheries 73: 20-25.

Gou, L.T.; Kang, J.Y.; Dai, P.; Wang, X.; Li., F.; Zhao, S.; Zhang, M.; Hua, M.M.; Lu, Y.; Zhu, Y.; Li, Z.; Chen, H.; Wu, L.G.; Li, D.; Fu, X.D; Li, J.; Shi, H.J.; Liu, M. 2017. Ubiquitination-Deficient Mutations in Human Piwi Cause Male Infertility by Impairing Histone-toProtamine Exchange during Spermiogenesis. Cell169 (6): 1090-1104 e13.

Herrera, A.A.; Cruz, R.R. 2001. Developmental biology of the supermale YY tilapia (Oreochromis niloticus): Histogenesis of the reproductive system. Science Diliman 13: 33-40.

Jing, J.; Wu, J.J.; Liu, W.; Xiong, S. T.; Ma, W.G.; Zhang, J.; Wang, W.; Gui, J-F.; Mei, J. 2014. Sex-Biased miRNAs in Gonad and Their Potential Roles for Testis Development in Yellow Catfish. PloS ONE 9(9): e107946

Kun-Tong, J.; Zhang, J.; Peng, J.; Lin, Z.; Yilin, J.; Yongming, Y.; Jieying C.; Yunhan, H.; Meisheng, Y. 2015. Identification of MicroRNAs in Zebrafish Spermatozoa. Zebrafish 12(6): 387-397.

Legendre, M.; Alavi, S. M. H.; Dzyuba, B.; Linhart, O.; Pokopchuk, G.; Cochet, C.; Dugué, R.; Cosson, J. 2016. Adaptations of semen characteristics and sperm motility to harsh salinity: Extreme situations encountered by the euryhaline tilapia Sarotherodon melanotheron heudelotii (Dumeril, 1859). Theriogenology 86(5): 1251-1267.

Li, W.; Buchinger, T. 2014. Pheromone Signaling: A Pissing Contest in Tilapia. Current Biology 24(18): 843-845.

Longrie, N.; Poncin, P.; Denoël, M.; Gennotte, V.; Delcourt, J. 2013. Behaviours Associated with Acoustic Communication in Nile Tilapia (Oreochromis niloticus). Plos One 8(4): e61467.

Lozano, C.A.; Gjerde, B.; Ødegård, J.; Rye, M.; Luan, T.D. 2014. Heritability estimates for male proportion in hybrids between Nile tilapia females (Oreochromis niloticus) and blue tilapia males (Oreochromis aureus). Aquaculture 430: 66-73.

Mataveli, M.; De Moraes, G.V.; Streit Jr, D.P.; Vargas Mendez, L.D.; Sakaguti, E.S.; Toninato, J.C.; Barbosa, R.C.; Merlini, L. 2007. Avaliação da qualidade do sêmen de tilàpia-do-nilo (Oreochromis niloticus), linhagem chitralada, suplementada com diferentes concentrações de vitamina C. B. Inst. Pesca, São Paulo 33(1): 1-7.

Megbowon, I.; Mojekwe, T.O. 2014. Tilapia sex reversal using methyl testosterone (MT) and it effect on fish, man and environment. Biotechnology 13(5): 213-216.

Mewes, J.K.; Meurer, F.; Tessaro, L.; Buzzi, A.H.; Syperreck, M.A.; Bombardelli, R.A. 2016. Diets containing crude glycerin damage the sperm characteristics and modify the testis histology of Nile tilapia broodstock. Aquaculture 465: 164-171.
Montejo, J.; Rosado, R.; GonzaLez, J.A. 2002. Evaluación del semen de Capitán de la Sabana, Eremophilus mutisii (pisces: Trichomycteridae). Rev. Asoc. Colomb. Ictiol. 5: 41-47.

Moraes, O.M.; Rodriguez, F.M.; Barbosa, G.M.; de Oliveira, F. V.; Solis M.L.D.; Souza A.E.; Bezerra, A.I.; Crovatto, V.G.; da Costa, D.V.; Viera, R.P. 2015 Effect Crude Protein Levels on the Broodstock Spermatic Quality of Nile tilapia (Oreochromis niloticus). American Journal of Experimental Agriculture 5(3): 192-199.

Mylonas, C.C; Duncan, N.J.; Asturiano, J.F. 2017. Hormonal manipulations for the enhancement of sperm production in cultured fish and evaluation of sperm quality. Aquaculture 472: 21-44.

Omasaki, S.K.; Charo-Karisa, H.; Kahi, A.K.; Komen, H. 2016. Genotype by environment interaction for harvest weight, growth rate and shape between monosex and mixed sex Nile tilapia. Aquaculture 458: 75-81.

Piñeros-Piñeros, R.; Cala-Cala, P. 1991. Motilidad, Morfología, Concentración y número de espermatozoides en reproductores de trucha Arco Iris Oncorhynchus mykiis (Pisces: Salmonidae). Revista Acad. Colomb. Ci. Exact. 18(68): 75-81

Robles, V.; Herráez, P.; Labbé, C.; Cabrita, E.; Pšenička, M.; Valcarce, D.G.; Riesco, M.F. 2017. Molecular basis of spermatogenesis and sperm quality. General and Comparative Endocrinology 245: 5-9.

Rurangwa, E.; Kime, D.E.; Ollevier, F.; Nash, J.P. 2004. The measurement of sperm motility and factors affecting sperm quality in cultured fish. Aquaculture 234: $1-28$.

Sánchez-Rodríguez, M.; Billard, R. 1977. Conservation se la motilité et du pouvoir fécondant du sperme de truite arc en ciel maintenu a des températures voisines de 0 ${ }^{\circ} \mathrm{C}$. Bulletin Francais de Pisciculture 265: 143-152.

Schill, D.J.; Heindel, J.A.; Matthew, R. Campbell, M.R.; Kevin, A.; Meyer, K.A.; Mamer, E.R.J.M. 2016. Production of a YY male brook trout broodstock for potential eradication of undesired brook trout populations. North American Journal of Aquaculture 78 (1): 72-83.

Sheikh, N.; Amiri, I.; Farimani, M.; Najafi, R.; Hadeie, J. 2008. Correlation between sperm parameters and sperm DNA fragmentation in fertile and infertile men. Ranian Journal of Reproductive Medicine 6(1): 13-18.

Sun, Y.L.; Jiang, D.N; Zeng, S.; Hu, C.J.; Ye, K.; Yang, C.; Yang, S.J.; Li, M.H.; Wang, D.S. 2014. Screening and characterization of sex-linked DNA markers and marker-assisted selection in the Nile tilapia (Oreochromis niloticus). Aquaculture 433: 19 - 27.

Valdebenito, I.C.; Fletcher, V.; Vera-Fernández, J. 2009. Factores fisicoquímicos que regulan la motilidad espermática en peces: aspectos básicos y aplicados. Una revision. Arch Med Vet 41: 97-106.

Vilela, D.A.R.; Silva, S.G.B.; Peixoto, M.T.D.; Godinho, H.P.; França, L.R. 2003. Spermatogenesis in teleost: insights from the Nile tilapia (Oreochromis niloticus) model. Fish Physiol Biochem 28: 187-190.

Wu, J.; Xiong, S.; Jing, J.; Chen, X.; Weimin-Wang, W.; Gui, J-F.; Mei, J. 2015. Comparative Transcriptome Analysis of Differentially Expressed Genes and Signaling Pathways between XY and YY Testis in Yellow Catfish. PLoS ONE 10(8): e0134626.

Zohar, Y.; Mylonas, C.C. 2001. Endocrine manipulations of spawning in cultured fish: from hormones to genes. Aquaculture 197: 99-136. 